\title{
Uses and Commercial Prospects for the Wine Palm, Attalea butyracea, in Colombia
}

\author{
Rodrigo Bernal, Gloria Galeano, Néstor García, \\ Ingrid Lorena Olivares and Carolina Cocomá
}

\section{Research}

\begin{abstract}
Attalea butyracea (Mutis ex L.f.) Wess. Boer is a massive and abundant palm that grows in dry areas of northern, central and eastern Colombia, where it ranks as one of the most useful plants. Thirty-six uses in eight use categories are recorded for this species in Colombia, including food, animal feed, medicine, construction, and technological and cultural uses. Most uses have only minor, local relevance, but some of them have potential that is worth exploring. The potential of the palm as a source of sugar, oil, palm heart, fiber, animal feed, and activated charcoal is discussed. Sugar production seems particularly promising; if the palm can be tapped through the inflorescence in the same way that other palms are tapped in Asia, sugar production in an integrated agrosilvopastoral system could be comparable to that of sugarcane planted for jaggery production. We suggest that this palm also has potential as a source of biofuel.
\end{abstract}

\section{Resumen}

Attalea butyracea (Mutis ex L.f.) Wess. Boer es una palma corpulenta, abundante en zonas secas del norte, centro y oriente de Colombia, donde llega a ser una de las plantas más útiles. Registramos treinta y seis usos en ocho categorías de uso para esta especie en Colombia, incluyendo alimento humano y animal, medicina, construcción, y usos tecnológicos y culturales. La mayoría de los usos tienen sólo importancia menor y local, pero algunos tiene potencial que vale la pena explorar. Discutimos el potencial de la palma como fuente de azúcar, aceite, palmito, fibra, alimento animal y carbón activado. La producción de azúcar parece particularmente prometedora; si se pudiera sangrar la palma por las inflorescencias como se hace con otras palmas en Asia, la producción de azúcar en un sistema agrosilvopastoril integrado sería comparable a la de la caña de azúcar que se planta para panela. Sugerimos que esta palma también tiene potencial como fuente de biocombustible.

\section{Introduction}

Attalea butyracea (Mutis ex L.f.) Wess. Boer is one of the most massive neotropical palms (Henderson et al. 1995), with a thick stem up to $50 \mathrm{~cm}$ in diameter and $15-20 \mathrm{~m}$ tall (Figure 1). It has a large crown with 30-40 pinnate leaves 6-7 $\mathrm{m}$ long, and large inflorescences enclosed in a thick, woody peduncular bract. The infructescences are large and pendant, and bear numerous fruits densely arranged, elliptical, 4.5-8.5 cm long and $2.5-4.5 \mathrm{~cm}$ in diameter, yellow to orange-brown in color (brown in some Amazonian populations), with a thick, woody endocarp and 2-3 (rarely one) narrowly elliptical seeds, $3-5 \mathrm{~cm}$ long, $0.5-1.2 \mathrm{~mm}$ thick.

This species is one of the most widely distributed of all American palms, and it grows in a variety of habitats, but

\section{Correspondence}

Rodrigo Bernal, Gloria Galeano and Ingrid Lorena Olivares, Instituto de Ciencias Naturales, Universidad Nacional de Colombia, Apartado 7495, Bogotá, COLOMBIA.

rgbernalg@unal.edu.co

Néstor García and Carolina Cocomá, Departamento de Biología, Facultad de Ciencias, Pontificia Universidad Javeriana, Bogotá, COLOMBIA.

nestor.garcia@javeriana.edu.co

Ethnobotany Research \& Applications 8:255-268 (2010)

Published: November 24, 2010 


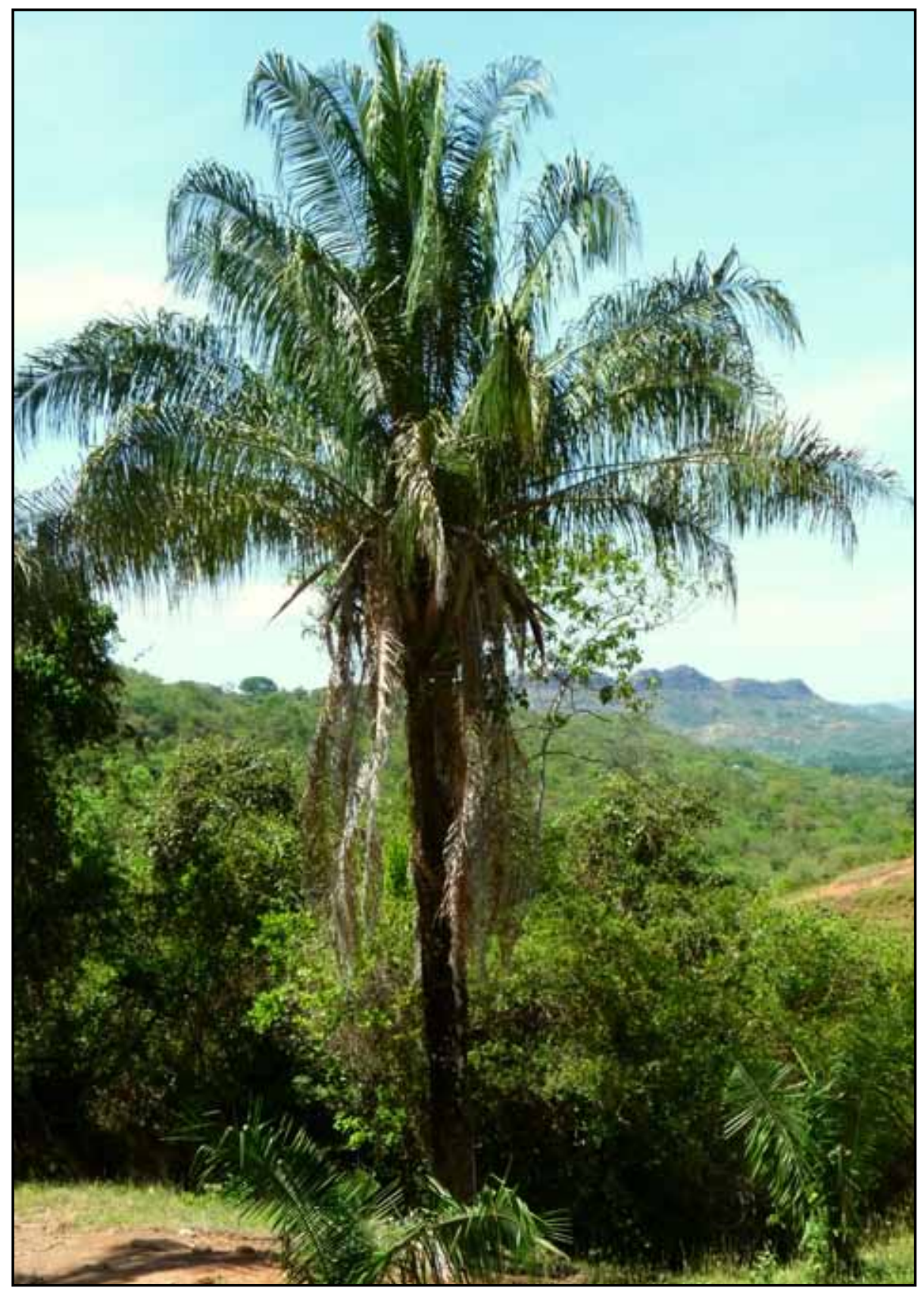

Figure 1. Attalea butyracea (Mutis ex L.f.) Wess. Boer in the Magdalena Valley, Colombia.

is particularly abundant in dry to slightly humid lowlands, where it regenerates abundantly in open areas, sometimes becoming a weed in pastures or forest plantations (Figure 2). In pastures, the fruits are eaten by cattle, pigs, and black vultures (Coragyps atratus) (Dugand 1972), which contribute to its dispersal.

In Colombia, $A$. butyracea is widespread in the Caribbean lowlands, the dry portions of the Cauca and Magdalena river valleys, the extensive savannas east of the Andes, known as the Llanos Orientales (Eastern Plains), extending to the northern end of the Amazon along the Guaviare river, and in other scattered localities throughout the Amazon, where it is scarce. In the Caribbean lowlands it is often a dominant element of areas that have been transformed into pastures, where its populations are favored by disturbance of the natural vegetation (Uribe et al. 2001). Nevertheless, in that region, as well as in the upper Magdalena River Valley, the palm has been eradicated from extensive areas of pastures and rice fields.

Throughout its range in Colombia, $A$. butyracea is widely used for a variety of purposes. Some of these uses have been discussed by Dugand (1959), Pérez Arbeláez (1978), and Cruz et al. (2009). In this paper, we review all documented uses of this species in Colombia, and discuss some prospects for commercializing this multi-purpose palm.

\section{Methods}

We conducted fieldwork between 1984 and 2009 in all the regions where $A$. butyracea grows in Colombia. In the Caribbean lowlands we studied palm use at Mingueo (Guajira), San Sebastián de Buenavista and El Banco (Magdalena), Chiriguaná and Chimichagua (Cesar), and Barranco de Yuca (Bolívar); in the Magdalena River Valley we studied palm use at Melgar and El Guamo (Tolima), and Nilo (Cundinamarca); in eastern Colombia we studied the palm on the Eastern Plains (Casanare); in the Amazon we visited the Putumayo, and Caquetá rivers in southern Colombia, and the Guaviare river, at the northern edge of the Amazon forest, and the southern limit of the large populations found in the Eastern Plains. 


\section{Bernal et al. - Uses and Commercial Prospects for the Wine Palm, Attalea butyracea, in Colombia}

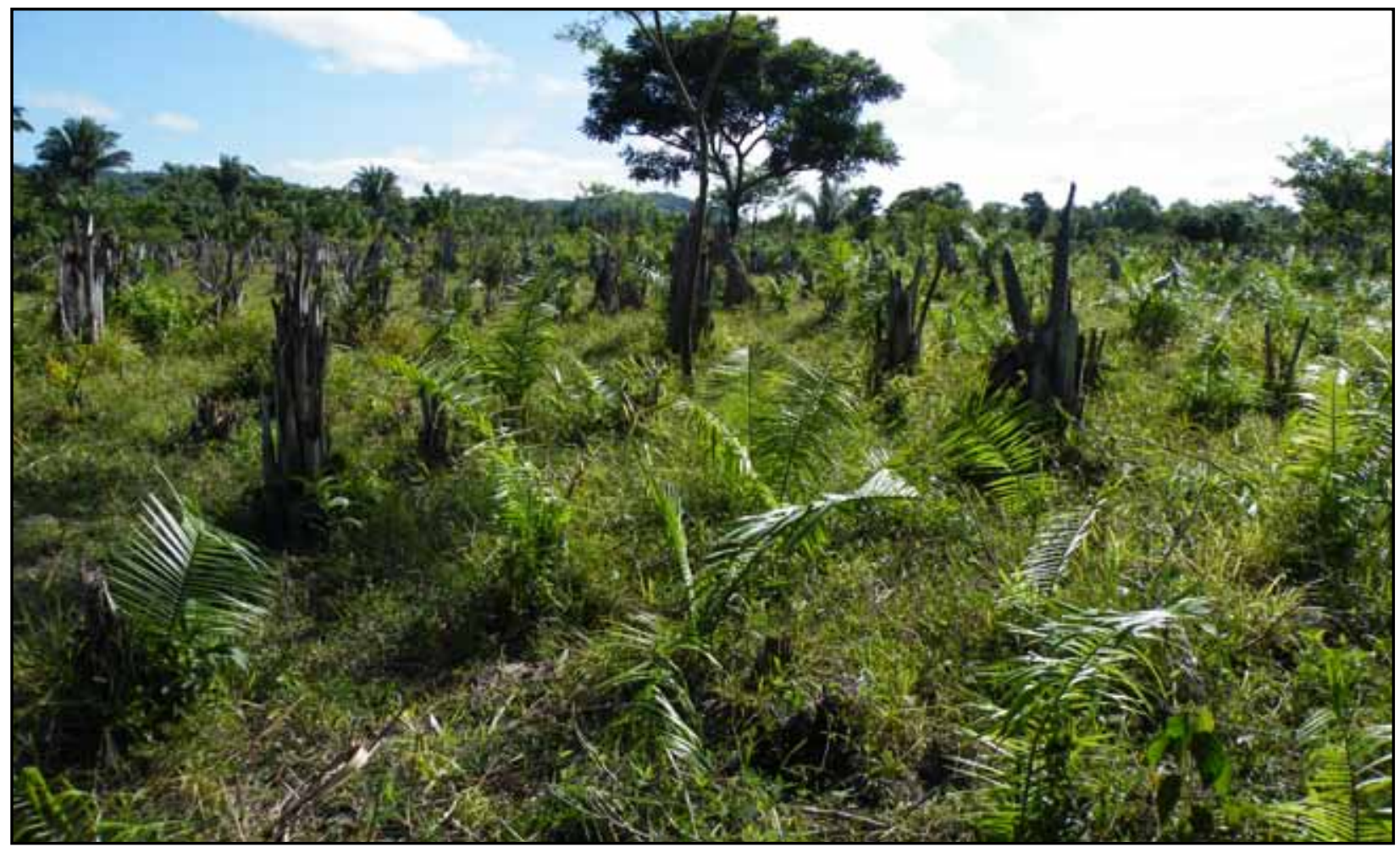

Figure 2. Attalea butyracea (Mutis ex L.f.) Wess. Boer as a weed in pastures near El Banco, Colombia.

At each locality, we conducted unstructured or semi-structured interviews directly with the people using the palm, and in many cases we witnessed the extraction of the products and the processing of derived products. We also collected information from published sources.

\section{Results}

The most widespread common name for $A$. butyracea in Colombia is palma de vino (wine palm), which is used in the Caribbean lowlands and the Magdalena River Valley, but the palm is also known by 16 other common names in Spanish: canambo (Caquetá, Putumayo); chapaja (Amazonas); corúa, curúa, or palma corúa (Caribbean lowlands); curumuta, corozo (the fruits) (Bolívar, Cesar, Córdoba, Magdalena); corozo de puerco (Valle del Cauca); corozo de marrano (Tolima, Valle del Cauca); corozo de vaca (Cundinamarca, Tolima); cuesco, palma de cuesco (Cundinamarca, Tolima, Valle del Cauca); palma de ramo (Vaupés); palma real (Amazonas, Caquetá, Casanare, Córdoba, Cundinamarca, Guainía, Guaviare, Huila, Tolima); and shebón (Río Amacayacu, Amazonas) (Bernal et al. 2006). In addition to Spanish, names have been documented for this species in 15 of the 64 Amerindian languages spoken today in Colombia: ümeh (Bora), sapohe (Cofán), kóchbot (Jitnu), nulyi (Kogui), buha tuuko (Muinane), mabai (Piapoco), ikutiñu (Sáliba), parumaboto (Sikuani), pa pa (Siona), kurua (Tikuna), barie (Uitoto), mĩã phãpú, phãpú (Wanano), kuluuala
(Wayuunaiki), tomohonase (Yagua), and mapanaré (Yukuna) (Marmolejo et al. 2008).

We documented 36 uses for $A$. butyracea in eight use categories: food (9 uses), animal feed (2), construction (4), technology (13), medicine (3), cosmetic (1), cultural (3), and ornamental (1) (Table 1). Products obtained range from artifacts for domestic use, with local application and little or no commercial value, to items involved in longer productive and market chains, generating a relevant income to harvesters. Below we will review the most relevant uses, grouped by use categories, whereas minor uses are included in Table 1.

\section{Food}

EDIBLE OIL. The seeds of the wine palm contain an edible oil, which was extracted in the Magdalena river valley as early as the late 18th century; this use prompted the Spanish botanist José Celestino Mutis to coin for the palm the specific epithet butyracea, literally meaning 'oilyielding.' Oil extraction persists today, but it is an occasional activity, and the oil obtained is used only for domestic purposes, with no trade involved. However, an oil processing plant is said to have existed in the coastal town of Barranquilla in the 1950s, which relied exclusively on wild-collected fruits of $A$. butyracea purchased from local peasants throughout the Caribbean lowlands of Colombia. According to local informants, the factory was un- 
Table 1. Uses of Attalea butyracea (Mutis ex L.f.) Wess. Boer in Colombia.

\begin{tabular}{|c|c|c|c|c|}
\hline Use category & \multirow[t]{2}{*}{ Organ used } & \multirow[t]{2}{*}{ Region } & \multirow[t]{2}{*}{ Locality } & \multirow[t]{2}{*}{ Reference } \\
\hline Product & & & & \\
\hline \multicolumn{5}{|l|}{ Food } \\
\hline $\begin{array}{l}\text { Fermented sap } \\
\text { as 'palm wine' }\end{array}$ & Sap & $\begin{array}{l}\text { Caribbean, } \\
\text { Magdalena } \\
\text { Valley }\end{array}$ & $\begin{array}{l}\text { Melgar and Honda } \\
\text { (Tolima), El Banco } \\
\text { and San Sebastián } \\
\text { de Buenavista } \\
\text { (Magdalena), } \\
\text { Chimichagua (Cesar) }\end{array}$ & $\begin{array}{l}\text { Cruz et al. 2009, Pérez } \\
\text { Arbeláez 1978, Pulgarín \& } \\
\text { Bernal 2004, R. Bernal, G. } \\
\text { Galeano \& N. García, pers. obs. }\end{array}$ \\
\hline $\begin{array}{l}\text { Fermented sap as } \\
\text { vinegar for cooking }\end{array}$ & Sap & Caribbean & Chimichagua (Cesar) & $\begin{array}{l}\text { R. Bernal \& N. García, } \\
\text { pers. obs. }\end{array}$ \\
\hline Drink & $\begin{array}{l}\text { Fruit } \\
\text { mesocarp }\end{array}$ & $\begin{array}{l}\text { Caribbean, } \\
\text { Magdalena } \\
\text { Valley }\end{array}$ & $\begin{array}{l}\text { Chimichagua (Cesar), } \\
\text { Melgar, (Tolima) }\end{array}$ & $\begin{array}{l}\text { I. Olivares, R. Bernal, } \\
\text { G. Galeano, \& N. } \\
\text { García, pers. obs. }\end{array}$ \\
\hline Oil from mesocarp & Fruit & $\begin{array}{l}\text { Caribbean, } \\
\text { Magdalena } \\
\text { Valley }\end{array}$ & Several localities & $\begin{array}{l}\text { R. Bernal, G. Galeano, \& } \\
\text { N. García, pers. obs. }\end{array}$ \\
\hline Oil from nut & Seed (nut) & $\begin{array}{l}\text { Caribbean, } \\
\text { Magdalena } \\
\text { Valley }\end{array}$ & Several localities & $\begin{array}{l}\text { Dugand 1959, Pérez Arbeláez } \\
\text { 1978, R. Bernal, G. Galeano, N. } \\
\text { García, \& I. Olivares, pers. obs. }\end{array}$ \\
\hline Edible mesocarp & $\begin{array}{l}\text { Fruit } \\
\text { mesocarp }\end{array}$ & Amazon & $\begin{array}{l}\text { Río Guaviare } \\
\text { (Guainía) }\end{array}$ & G. Galeano, per. obs. \\
\hline Edible nut & Seed (nut) & $\begin{array}{l}\text { Magdalena } \\
\text { Valley, } \\
\text { Amazon }\end{array}$ & $\begin{array}{l}\text { El Guamo (Tolima) } \\
\text { and Río Guaviare } \\
\text { (Guainía) }\end{array}$ & $\begin{array}{l}\text { C. Cocomá \& N. García, pers. } \\
\text { obs.; G. Galeano, pers. obs. }\end{array}$ \\
\hline Palm heart & Stem & $\begin{array}{l}\text { Caribbean, } \\
\text { Amazon }\end{array}$ & $\begin{array}{l}\text { El Banco } \\
\text { (Magdalena), Río } \\
\text { Guaviare (Guainía) }\end{array}$ & $\begin{array}{l}\text { Cruz et al. 2009, Pérez } \\
\text { Arbeláez 1978, R. Bernal, N. } \\
\text { García \& G. Galeano, pers. obs. }\end{array}$ \\
\hline $\begin{array}{l}\text { Beetle larvae from } \\
\text { decaying stem }\end{array}$ & Stem & Amazon & Río Guaviare & $\begin{array}{l}\text { R. Bernal \& G. Galeano, } \\
\text { pers. obs. }\end{array}$ \\
\hline \multicolumn{5}{|l|}{ Animal Feed } \\
\hline $\begin{array}{l}\text { Feed for cattle } \\
\text { and pigs }\end{array}$ & Fruit & $\begin{array}{l}\text { Caribbean, } \\
\text { Cauca } \\
\text { valley }\end{array}$ & Several localities & $\begin{array}{l}\text { R. Bernal, G. Galeano \& } \\
\text { N. García, pers. obs. }\end{array}$ \\
\hline $\begin{array}{l}\text { Mesocarp cake } \\
\text { for pigs }\end{array}$ & $\begin{array}{l}\text { Fruit } \\
\text { mesocarp }\end{array}$ & Caribbean & Magangué (Bolívar) & $\begin{array}{l}\text { C. Cocamá \& N. } \\
\text { García, pers. obs. }\end{array}$ \\
\hline \multicolumn{5}{|l|}{ Construction } \\
\hline Thatch & Mature leaves & All & Throughout its range & $\begin{array}{l}\text { Cruz et al. 2009, Dugand } \\
\text { 1959, Moreno et al. } 1993\end{array}$ \\
\hline Walls and doors & Leaf rachis & Caribbean & Chimichagua (Cesar) & $\begin{array}{l}\text { R. Bernal \& N. García, } \\
\text { pers. obs. }\end{array}$ \\
\hline $\begin{array}{l}\text { Posts for provisional } \\
\text { shelters }\end{array}$ & Split stems & $\begin{array}{l}\text { Eastern } \\
\text { Plains }\end{array}$ & Casanare & G. Galeano, pers. obs. \\
\hline Fences & $\begin{array}{l}\text { Leaves (whole } \\
\text { or just rachis) }\end{array}$ & Caribbean & $\begin{array}{l}\text { Hatillo de la Sabana } \\
\text { (Magdalena) }\end{array}$ & $\begin{array}{l}\text { R. Bernal \& N. García, } \\
\text { pers. obs. }\end{array}$ \\
\hline \multicolumn{5}{|l|}{ Technological } \\
\hline $\begin{array}{l}\text { Hats and other woven } \\
\text { artifacts (wallets, mats, } \\
\text { bags, belts, dolls) }\end{array}$ & Leaf & $\begin{array}{l}\text { Caribbean, } \\
\text { Magdalena } \\
\text { Valley }\end{array}$ & $\begin{array}{l}\text { Chimichagua } \\
\text { (Cesar), El Banco } \\
\text { (Magdalena), El } \\
\text { Guamo (Tolima) }\end{array}$ & $\begin{array}{l}\text { Cruz et al. 2009, Pérez } \\
\text { Arbeláez 1978, R. Bernal, C. } \\
\text { Cocomá \& N. García, pers. obs. }\end{array}$ \\
\hline
\end{tabular}


Bernal et al. - Uses and Commercial Prospects for the Wine Palm, Attalea butyracea, in Colombia

\begin{tabular}{|c|c|c|c|c|}
\hline Use category & \multirow[t]{2}{*}{ Organ used } & \multirow[t]{2}{*}{ Region } & \multirow[t]{2}{*}{ Locality } & \multirow[t]{2}{*}{ Reference } \\
\hline Product & & & & \\
\hline Fans & Leaf & $\begin{array}{l}\text { Caribbean, } \\
\text { Magdalena } \\
\text { Valley }\end{array}$ & Several localities & $\begin{array}{l}\text { Cruz et al. 2009, R. Bernal, C. } \\
\text { Cocomá \& N. García, pers. obs. }\end{array}$ \\
\hline Fly brushes & Infructescence & Caribbean & $\begin{array}{l}\text { Chimichagua (Cesar), } \\
\text { El Banco (Magdalena) }\end{array}$ & $\begin{array}{l}\text { Cruz et al. 2009, R. Bernal } \\
\& \text { N. García, pers. obs. }\end{array}$ \\
\hline Brooms & $\begin{array}{l}\text { Pinna } \\
\text { midvein }\end{array}$ & Caribbean & $\begin{array}{l}\text { Chimichagua } \\
\text { (Cesar), El Banco } \\
\text { (Magdalena), El } \\
\text { Guamo (Tolima) }\end{array}$ & $\begin{array}{l}\text { R. Bernal, N. García \& C. } \\
\text { Cocomá, pers. obs. }\end{array}$ \\
\hline $\begin{array}{l}\text { Woven backpack } \\
\text { (catumare) }\end{array}$ & Leaf & Amazonia & Río Guaviare & $\begin{array}{l}\text { R. Bernal \& G. Galeano, } \\
\text { pers. obs. }\end{array}$ \\
\hline $\begin{array}{l}\text { Mattress made of two } \\
\text { parallel leaf fragments } \\
\text { with interwoven pinnae }\end{array}$ & Leaf & Amazonia & Río Guaviare & G. Galeano, pers. obs. \\
\hline $\begin{array}{l}\text { Hen's nests made } \\
\text { from woven leaves }\end{array}$ & Leaf & Amazonia & Río Guaviare & G. Galeano, pers. obs. \\
\hline $\begin{array}{l}\text { Guiding sticks for } \\
\text { firework rockets }\end{array}$ & Leaf rachis & $\begin{array}{l}\text { Magdalena } \\
\text { Valley }\end{array}$ & El Guamo (Tolima) & $\begin{array}{l}\text { C. Cocomá \& N. } \\
\text { García, pers. obs. }\end{array}$ \\
\hline Sealing for fruit crates & Leaf rachis & $\begin{array}{l}\text { Magdalena } \\
\text { Valley }\end{array}$ & El Guamo (Tolima) & $\begin{array}{l}\text { C. Cocomá \& N. } \\
\text { García, pers. obs. }\end{array}$ \\
\hline $\begin{array}{l}\text { Perianths sewn into } \\
\text { a ring for holding } \\
\text { totumas (containers } \\
\text { made from calabash } \\
\text { tree fruits) }\end{array}$ & Fruit perianth & Caribbean & Chimichagua (Cesar) & $\begin{array}{l}\text { R. Bernal \& N. García, } \\
\text { pers. obs. }\end{array}$ \\
\hline $\begin{array}{l}\text { Beads sewn to make } \\
\text { a cover for car seats, } \\
\text { which improves air } \\
\text { circulation between the } \\
\text { driver and the seat. }\end{array}$ & $\begin{array}{l}\text { Polished } \\
\text { endocarps }\end{array}$ & $\begin{array}{l}\text { Magdalena } \\
\text { Valley }\end{array}$ & Melgar, (Tolima) & N. Pulgarín, pers. comm. \\
\hline $\begin{array}{l}\text { Keeping mosquitos } \\
\text { away }\end{array}$ & $\begin{array}{l}\text { Burned } \\
\text { endocarps }\end{array}$ & Caribbean & Chimichagua (Cesar) & $\begin{array}{l}\text { R. Bernal \& N. García, } \\
\text { pers. obs. }\end{array}$ \\
\hline Fertilizer & Decaying stem & Caribbean & Chimichagua (Cesar) & N. García, pers. obs. \\
\hline \multicolumn{5}{|l|}{ Medicinal } \\
\hline $\begin{array}{l}\text { Seed cake for } \\
\text { treating goiter }\end{array}$ & Seed & Caribbean & Chimichagua (Cesar) & Cruz et al. 2009 \\
\hline $\begin{array}{l}\text { Seed oil for treating } \\
\text { bronchial ailments }\end{array}$ & Seed & $\begin{array}{l}\text { Magdalena } \\
\text { Valley }\end{array}$ & Nilo, Cundinamarca & I. Olivares, pers. obs. \\
\hline $\begin{array}{l}\text { Fermented sap to } \\
\text { clean the vagina, and } \\
\text { increase fertility }\end{array}$ & Sap & Caribbean & Chiriguaná (Cesar) & R. Bernal, pers. obs. \\
\hline \multicolumn{5}{|l|}{ Cosmetic } \\
\hline Seed oil for hair care & Seed & Caribbean & Chimichagua (Cesar) & N. García, pers. obs. \\
\hline \multicolumn{5}{|l|}{ Cultural } \\
\hline $\begin{array}{l}\text { Spear leaves for } \\
\text { greeting Jesus during } \\
\text { Easter's Palm Sunday }\end{array}$ & Leaf & $\begin{array}{l}\text { Caribbean, } \\
\text { Magdalena } \\
\text { Valley }\end{array}$ & Many localities & $\begin{array}{l}\text { R. Bernal, G. Galeano \& } \\
\text { I Olivares, pers. obs. }\end{array}$ \\
\hline
\end{tabular}




\begin{tabular}{|c|c|c|c|c|}
\hline Use category & \multirow[t]{2}{*}{ Organ used } & \multirow[t]{2}{*}{ Region } & \multirow[t]{2}{*}{ Locality } & \multirow[t]{2}{*}{ Reference } \\
\hline Product & & & & \\
\hline $\begin{array}{l}\text { Staminate } \\
\text { inflorescences to } \\
\text { decorate statues of } \\
\text { saints during Easter's } \\
\text { Maundy Thursday } \\
\text { and Good Friday }\end{array}$ & $\begin{array}{l}\text { Staminate } \\
\text { inflorescence }\end{array}$ & Caribbean & Chimichagua (Cesar) & $\begin{array}{l}\text { R. Bernal \& N. García, } \\
\text { pers. obs. }\end{array}$ \\
\hline $\begin{array}{l}\text { Old infructescence } \\
\text { as Christmas tree }\end{array}$ & Infructescence & $\begin{array}{l}\text { Magdalena } \\
\text { Valley }\end{array}$ & Nilo (Cundinamarca) & I. Olivares, pers. obs. \\
\hline \multicolumn{5}{|l|}{ Ornamental } \\
\hline $\begin{array}{l}\text { The whole palm as } \\
\text { an ornamental tree }\end{array}$ & $\begin{array}{l}\text { The whole } \\
\text { plant }\end{array}$ & \begin{tabular}{|l|} 
Caribbean, \\
Cauca \\
Valley, \\
Magdalena \\
Valley
\end{tabular} & Many localities & \begin{tabular}{|l} 
R. Bernal, G. Galeano, N. \\
García \& I. Olivares, pers. obs.
\end{tabular} \\
\hline
\end{tabular}

successful because of the peasants' mischievous habit of sneaking stones into the fruit sacks, in order to increase their weight. Whatever the truth of this assertion, the fact is that no trade exists today for the fruits.

The process for extracting oil from the seeds consists in peeling the fruit, cracking the hard endocarps, roasting and grinding the seeds, and then boiling the resulting product to obtain the oil. When done in this way, the oil has a dark color. If the seeds are not roasted, the oil has a clear and crystalline color, but its extraction takes longer.

Dugand (1959) described the oil extracted from the seeds as containing 50 $60 \%$ of semisolid and white oil, much resembling coconut oil. A study of the organoleptic and physicochemical properties of the oil from the seeds found that it fulfills the technical requirements to be used for human consumption in Colombia (see Table 3 in Devia et al. 2002); these authors concluded that the oil has potential to be used in cosmetics (soap, body cream, hair lotion), and to produce margarine.

In the Caribbean lowlands, oil is also extracted from the mesocarp by boiling the entire fruit, and the obtained floating oil is then fried and bottled. It is yelBoer for extracting sap. low and turbid, and is considered of lower quality than that extracted from the seeds.

SAP FOR FERMENTED BEVERAGE. In the Caribbean lowlands and in the Magdalena River Valley it is a common practice to fell the adult palms to obtain the sap, which is fermented and sold as 'palm wine'. Pulgarín \& Bernal (2004) have documented the process. Once the palm has been felled, the 10-15 leaves that face upwards are removed, and a box-shaped cavity $20 \times 30 \times 20 \mathrm{~cm}$ is cut out in the meristematic area using a machete (Figure 3). Sap flowing into this cavity is collected every day. An 8

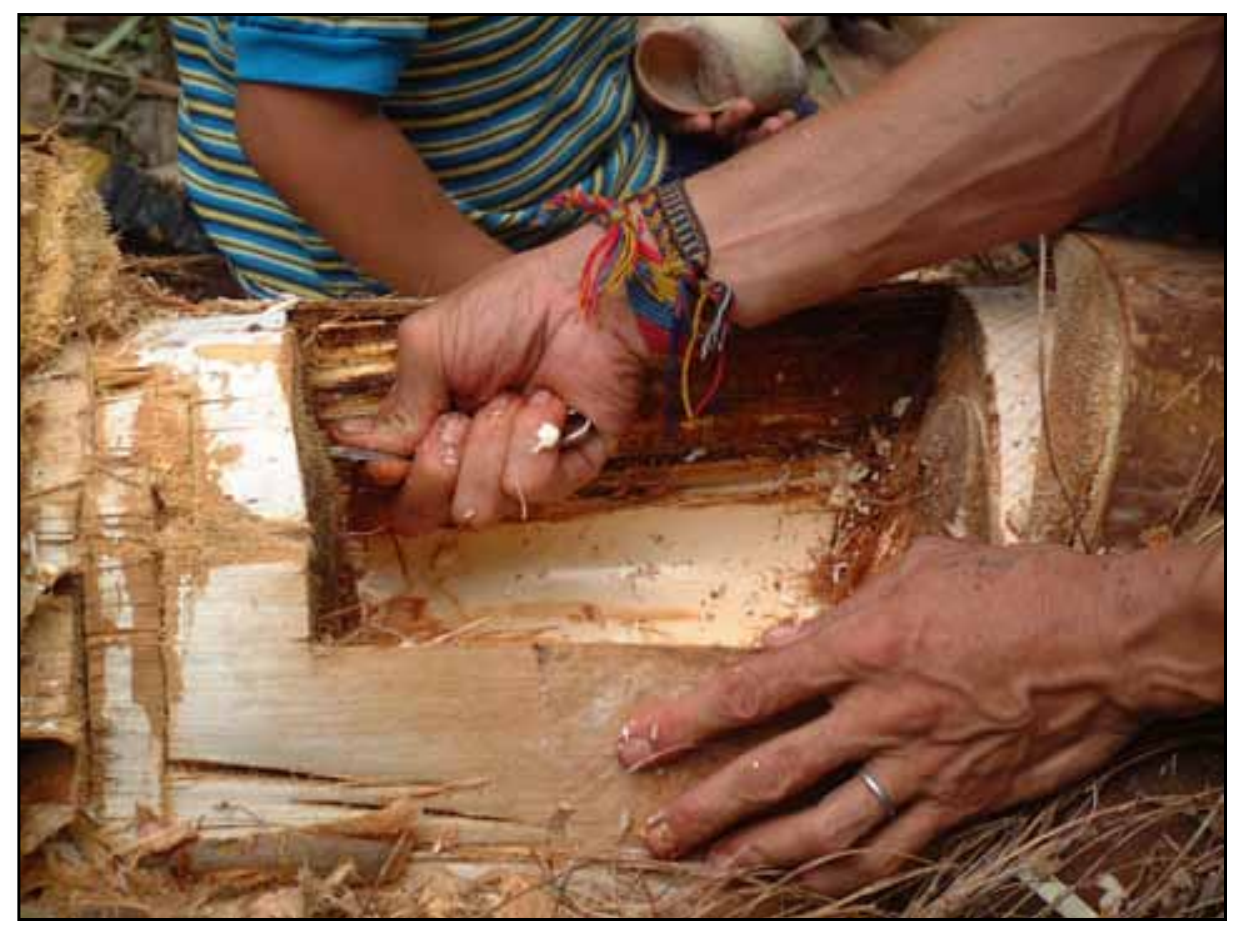

Figure 3. Cutting a box out of the meristem of Attalea butyracea (Mutis ex L.f.) Wess.

www.ethnobotanyjournal.org/vol8/i1547-3465-08-255.pdf 


\section{Bernal et al. - Uses and Commercial Prospects for the Wine Palm, Attalea butyracea, in Colombia}

$\mathrm{m}$ tall palm produced about one liter of sap per day over a period of 20-30 days. Along the Guaviare River, where sap is occasionally extracted by colonos, taller palms are said to produce up to 3.7 liters per day.

The sap has a whitish, turbid appearance, and a sucrose content of $11.7 \%$ (Pulgarín \& Bernal 2004). It is left to ferment, is bottled in reused soda drink bottles, and sold as 'palm wine' at roadside stalls mainly along major roads in the Magdalena River Valley. The price of palm wine in August 2009 was US\$2.7/liter near Melgar, Tolima and US\$ 0.8/liter Near El Banco, Magdalena. Thus, a 5-10 m tall

Melgar, the fallen ripe fruits of $A$. butyracea are picked up from the ground, macerated and boiled with sugar for several hours, sometimes adding cow bones in the process, to produce a yellow beverage locally called chicha de corozo or chicha de cuesco, which is bottled in reused soda bottles and sold alongside palm wine. Price of chicha de corozo near Melgar, Tolima was US\$2.7/liter in October 2009. As in the case of palm wine, the production of this beverage is a minor activity, and the product is usually sold only at the producer's home. The same process was pointpalm with an estimated age of 15-25 years, produces an as a past use no longer practiced there. Instead of making income of about US\$ 16-54 in 20 days; this figure may be higher in the Magdalena Valley, where the fermenting sap is mixed with water. The commerce of palm wine is a minor activity that involves few people at each locality; the product is usually sold only at the producers' homes, and it does not reach markets. The production of jaggery out of palm sap, as practiced in Asia, is unknown in Colombia. In Cesar, on the Caribbean lowlands, people believe that palm wine 'strengthens the blood' and acts as an aphrodisiac.

PALM HEART. In the Caribbean lowlands, the palm heart of $A$. butyracea is a highly appreciated food but it is not a component of the daily diet, and is consumed only occasionally. Often it is eaten together with panela (jaggery made from sugarcane). The palm heart is obtained from palms that are about to start producing a stem (Figure 4). Palms of this size produce about $2 \mathrm{~kg}$ of palm heart, the taste of which is comparable to that of commercial palm hearts such as Euterpe oleracea Mart. or Bactris gasipaes Kunth. There is no trade of this product, and there is no particular season for its use.

BEVERAGE FROM THE MESOCARP. In the Magdalena River Valley, near the town of

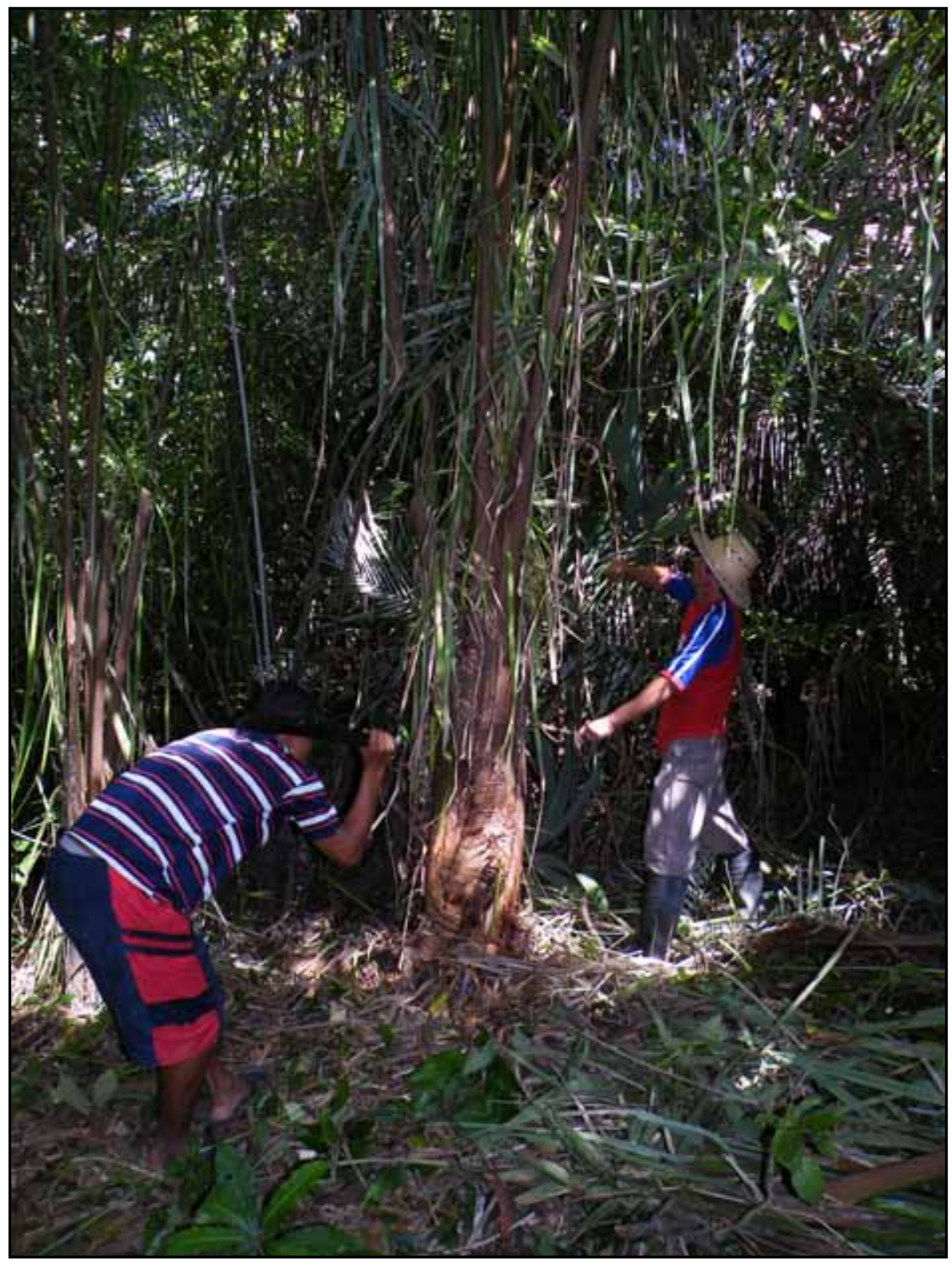

Figure 4. Extracting palm heart of Attalea butyracea (Mutis ex L.f.) Wess. Boer near El Banco, Colombia. 


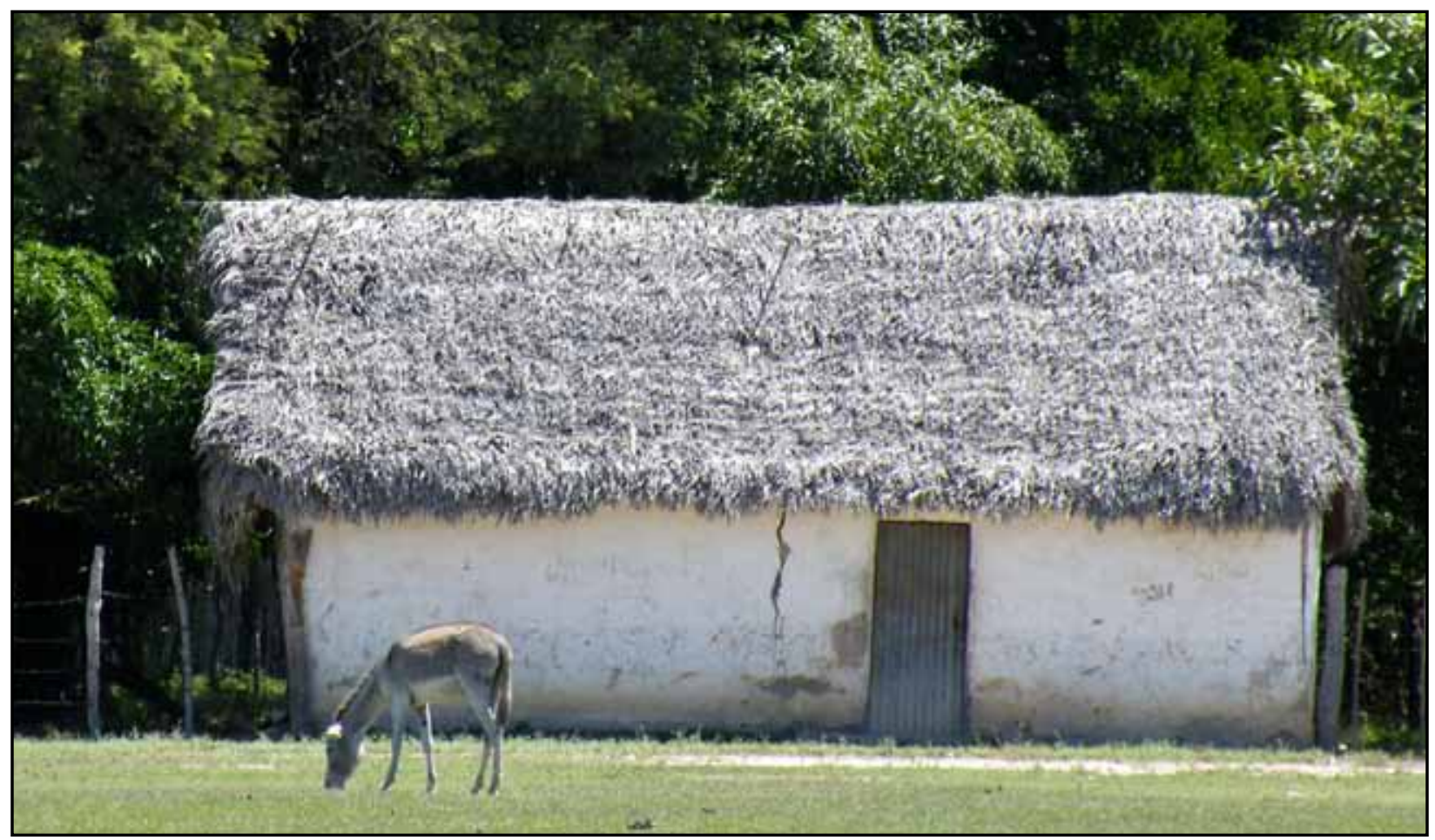

Figure 5. A house thatched with leaves of Attalea butyracea (Mutis ex L.f.) Wess. Boer near El Banco, Colombia.

chicha, the Piapoco Indians eat the mesocap, after boiling the fruits for about one hour and peeling them.

BEETLE LARVAE BREEDING IN THE DECAYING STEMS. This use is known only in the Amazon region, where we have found it among the Sikuani and Piapoco of the Guaviare River, and the Yukuna of the Caquetá River. In these areas, the Indians fell adult palms in order to collect the numerous beetle larvae (probably Rhynchophorus palmarum L.) that develop in the decaying stems. Five days after the palm has been felled, the beetle larvae begin to grow and they are ready for consumption after about one month. These larvae are very oily and they are eaten raw or roasted; they have a good taste and are considered a delicacy.

\section{Animal Feed}

In several areas of Colombia, pigs, which are usually left free to look for food on their own, eagerly seek the fallen ripe fruits of the wine palm. The pigs eat not only the pulpy mesocarp, but apparently, they can also break the hard, woody endocarp to reach the oily seed. This use is the origin of the name corozo de puerco (pig's nut), applied to the palm in some areas of the upper Cauca Valley. As mentioned above, cattle also eat the fallen fruits, but they apparently swallow the entire endocarps, which, according to local claims, sometimes cause them intestinal obstruction and death. In some areas of the Caribbean, the fruits are collected and the mesocarp is made into a thick cake used to feed pigs.

\section{Construction}

LEAVES FOR THATCH. The leaves of $A$. butyracea are one of the preferred thatching materials in the areas where the palm abounds. In many small villages of the Caribbean coast and along the Guaviare River, it is still common to see houses thatched with this palm (Figure 5), although tin roofs are progressively replacing this material.

For thatching, usually most of the mature leaves are harvested, leaving only those that are still too tender (these can be recognized by their yellowish color). Usually, 14-30 leaves are obtained from each palm. Leaves are harvested when the moon is waning.

A 3-4 $\mathrm{m}$ long portion in the center of the leaf is selected, discarding the apex, where the leaflets are very short, and the base, where the rachis is too thick. The selected leaf fragment is usually split lengthwise along the rachis, and the halves are placed with the rachis transverse to the roof slope, and the leaflet upper surface facing into the house (Figure 6). Along the Guaviare River and in some places in the Caribbean lowlands, leaves are used without splitting them into two halves; in this case, the leaflets of one leaf are woven with those of the neighboring leaf (Caribbean lowlands), or a cut is made at the base of the leaflets in one side of the leaf, so that they can be bent onto the leaflets of the opposite side, and remain attached to the rachis by their midveins (along the Guaviare River). 


\section{Bernal et al. - Uses and Commercial Prospects for the Wine Palm, Attalea butyracea, in Colombia}
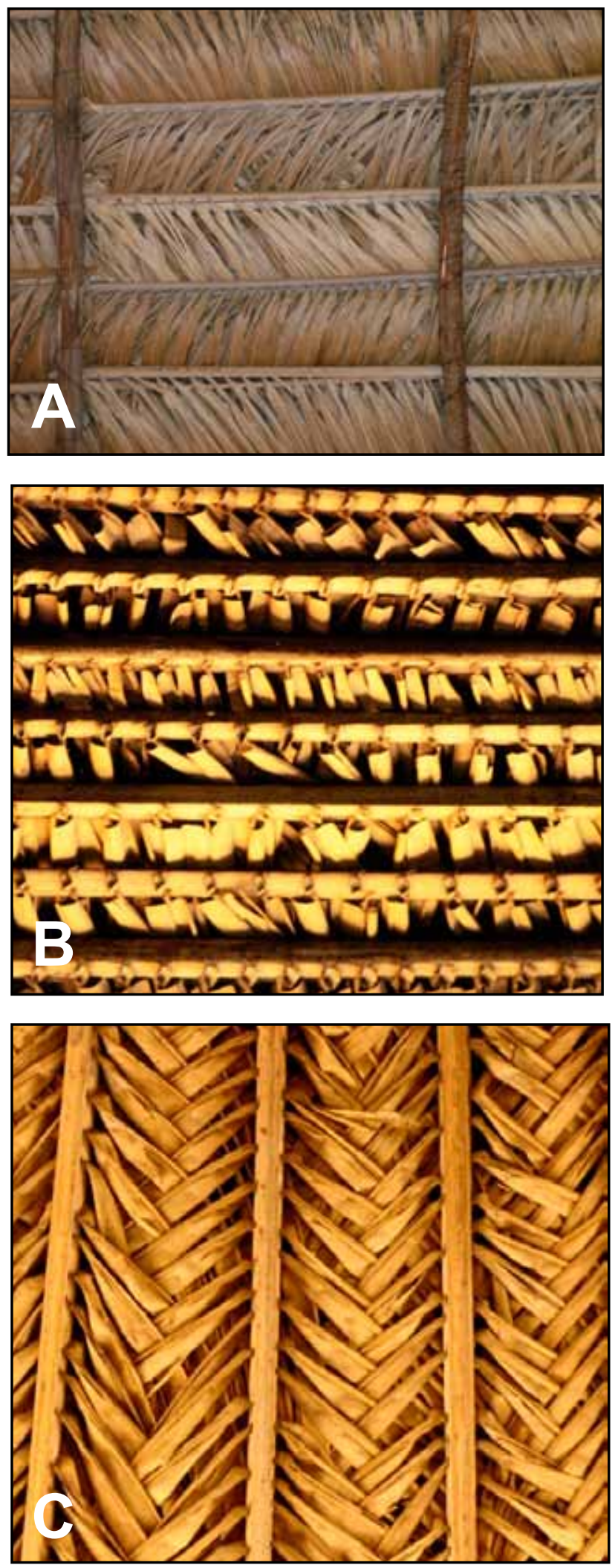

Figure 6. Details of thatch of Attalea butyracea (Mutis ex L.f.) Wess. Boer in Colombia.
There are several styles of thatch that vary according to how the leaf segments are placed one alongside the other (Figure 6A-C). Each type of thatch has a different appearance when seen from the inside, and they also vary in duration. The most durable (and the one that requires the largest number of leaves) is a thatch in which the rachises are placed next to each other, with a minimum space in between. In this case, the rachises must be alternated, so that the thinner end of one rachis lies next to the thicker end of the next one, thus guaranteeing that they will remain parallel. With this technique, $6-12$ leaves $/ \mathrm{m}^{2}$ are required, depending on whether the leaves are split or not.

Usually, there is no market for the leaves, and people harvest what they require for their own needs. However, in some areas of the Magdalena Valley that are popular vacation spots for people from Bogotá, kiosks and restaurants are often thatched with wine palm leaves, a service offered by some local peasants. One hundred leaves sold for US\$ 67 in September 2009 near Melgar, in the upper Magdalena Valley.

In the dry climate of the Caribbean or the Magdalena Valley, a good thatch of wine palm can last up to 10 years (Dugand 1959, Moreno et al. 1993), along the wetter Guaviare River, for 5-12 years, and farther south, under the stronger rainy regime of the Amazon, a thatch hardly lasts more than three years.

ENTIRE LEAVES OR LEAF RACHIS FOR FENCES. In the Caribbean lowlands, the whole leaf or the leaf rachis of the wine palm are used as a material for fencing courtyards. For this use, as with thatch, the base and the apex are removed, leaving only the central portion of the rachis, which is about $4 \mathrm{~cm}$ wide.

\section{Technological Use}

BROOMS. In the Caribbean lowlands, the leaflet midvein of spear leaves is used to make brooms. For this purpose, the 2-3 largest spear leaves are cut (there are usually 3-4 developing leaves at a time), the leaflets are taken in groups or 4-5 at a time, and their midveins are separated from their laminas by a single cut made with a knife. Only at this point are the midveins detached from the leaf rachis. In this way, all the midveins of about 200 leaflets per leaf are extracted in a few minutes. The midveins are packed in bundles of about $15 \mathrm{~kg}$ and tied with another leaflet for transportation to the village.

Small bundles of about 10 midveins each are then braided along a string about $2 \mathrm{~m}$ long stretched between two house poles, and the final braid is then spirally wrapped around a stick. The resulting broom (Figure 7) is rougher than the other two kinds of palm brooms produced in the area from the midveins of Elaeis oleifera (Kunth) Cortés and Astrocaryum malybo $\mathrm{H}$. Karst. A broom made from $A$. 


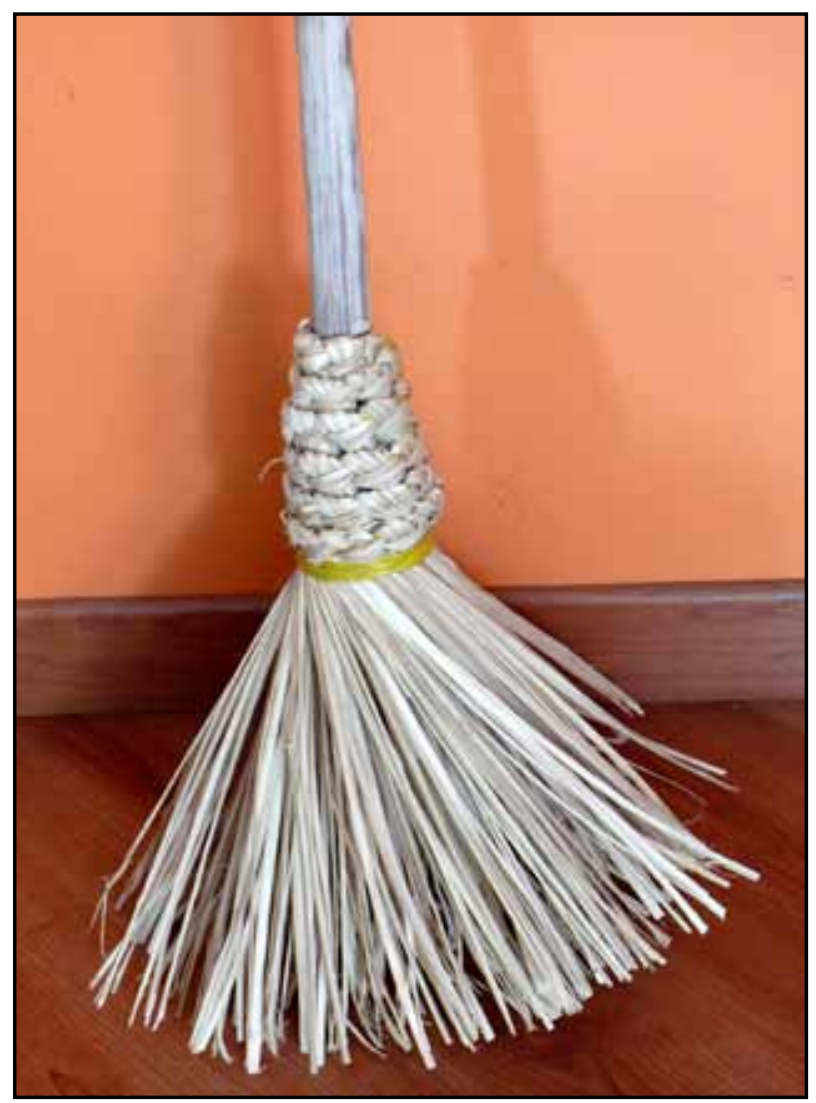

Figure 7. Broom made with the leaflet midveins of Attalea butyracea (Mutis ex L.f.) Wess. Boer at Chimichagua, Colombia.

butyracea is suitable for sweeping rough surfaces such as courtyards or streets.

Wine palm brooms are common in the Caribbean lowlands, and their price at the production center was US\$ 0.75 per unit in August 2009. There is a local market for them throughout the towns of the region, and they even reach supermarkets. Apparently, there is a larger industry using wine palm midveins outside the area, as there is trade for the raw midveins, which are bought from local peasants and carried by truckloads to Barranquilla and Bucaramanga, Colombia's fourth and fifth largest cities, respectively.

We were unable to track the product to its final destination, and do not know its use, although it may also be for broom making. In any case the harvest of this product is a widespread income-generating activity in the areas where the palm abounds; in Barranco de Yuca (Bolívar) and Hatillo de la Sabana (Cesar), two small villages of about 500 inhabitants each, most households were involved in this business in August 2005 and 2009, respectively, although perhaps not as their major activity. It is important enough that the harvest activity has its own verb - pajitiar, literally meaning 'to harvest straw.'
HATS AND OTHER HANDCRAFTS. After the midvein is removed, the lamina of the leaflets is used to make hats and other handicrafts such as bags, mats, wallets, belts, Christmas dolls, and costumes (Figure 8). Two kinds of hats are produced -woven and sewn. Woven hats are not common, and we have seen them only at El Banco (Magdalena), where only one person makes them. Sewn hats are the most common and perhaps they are also more durable. They are made by producing a long strip of

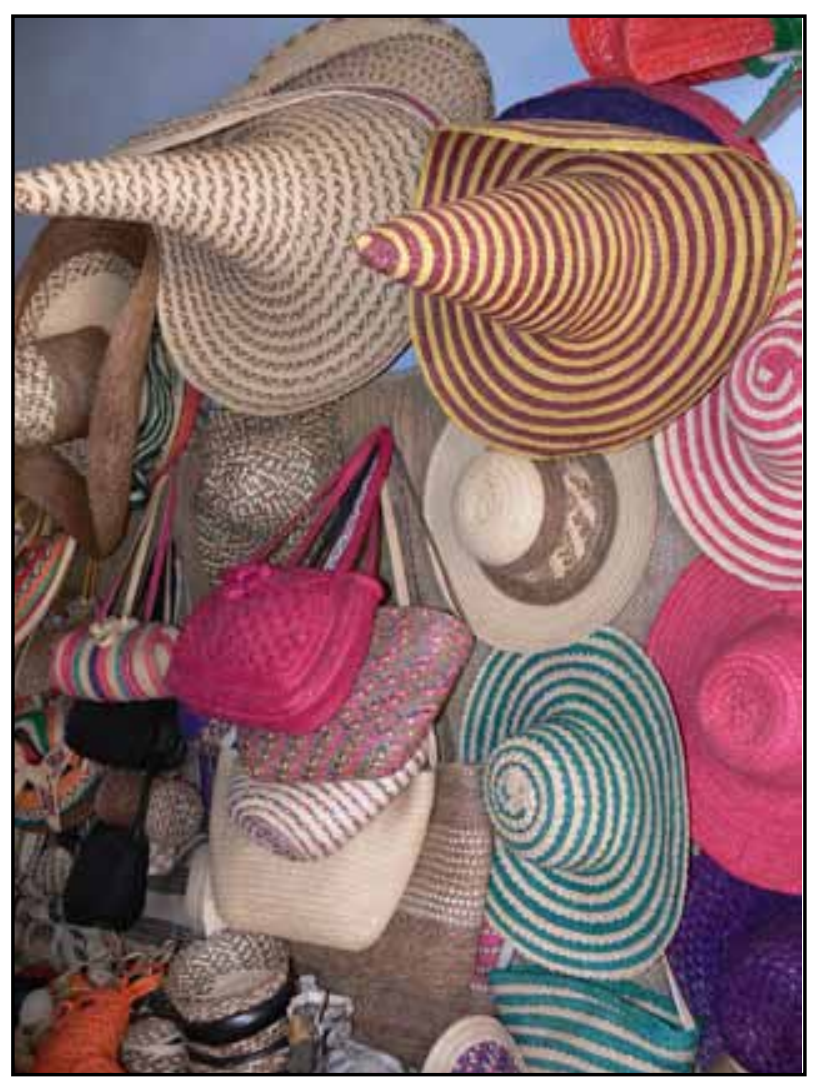

Figure 8. Products made with fiber of Attalea butyracea (Mutis ex L.f.) Wess. Boer at El Guamo, Tolima, Colombia.

braided leaflets that is about $1 \mathrm{~cm}$ wide. The strip is sewn in a spiral to shape the hat.

Sewn hats from Attalea are traditional in the upper Magdalena River Valley. In this region, expert harvesters climb up a bamboo pole to reach the crown of tall palms, where they cut three or four spear leaves. They then cut off the leaflets and remove the midvein; the leaflet laminas are then cooked for up to 10 minutes, and left to dry and bleach under the sun for a few hours. After the initial drying, they are left to dry for three more days, but are slightly moistened at night, so that the laminas acquire the desired texture and do not roll up. Once completely dry and flat, each lamina is divided into three parts, which are braided to obtain the strips. Sometimes, the strips are dyed with chemical products. 


\section{Bernal et al. - Uses and Commercial Prospects for the Wine Palm, Attalea butyracea, in Colombia}

In the region near El Guamo (Tolima), hundreds of families are partly devoted to activities related to the wine palm (e.g., harvesting spear leaves, processing fibers or sewing handicrafts). The hats and other sewn products are common in stores and markets throughout the region or in roadside stalls along major roads. In September 2009, the price of about $10 \mathrm{~m}$ of strip was US\$ 0.7 ; of a hat, US\$ 0.6-1.5; of a bag, US\$ 8-10; and of a mat, US\$ 45 .

CARRYING BASKETS. Along the Guaviare River, the leaves are used to weave the catumare, a disposable backpack that is quickly made in situ, and which is used to carry heavy game or products, such as manioc, from the forest plots. In order to weave a catumare, two leaf fragments about $70 \mathrm{~cm}$ long are cut, their rachises placed parallel at about $40 \mathrm{~cm}$ from each other, and their pinnae woven to shape the backpack.

FANS. Small leaf fragments of the wine palm, comprising about nine leaflets on each side, are woven into small square fans (Figure 9). For this purpose, a leaf fragment close to the leaf apex is chosen, as the rachis is thinner at this place.

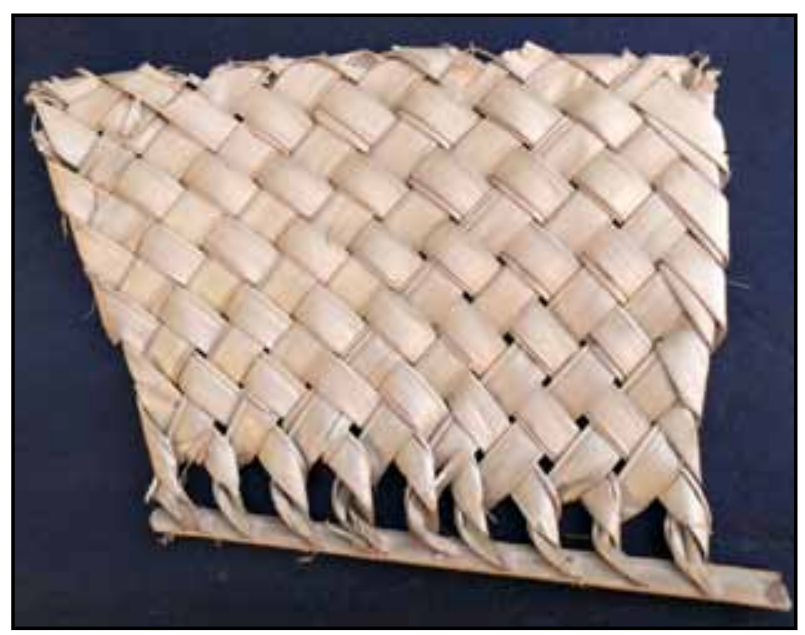

Figure 9. A fan woven from the leaf of Attalea butyracea (Mutis ex L.f.) Wess. Boer at Hatillo de La Sabana, Colombia.

THE MUSENGUE -A FLY BRUSH. One of the most unusual palm products found in Colombia is the musengue (Figure 10), a horsetail-like implement used to keep flies or mosquitoes away, much in the same way as horses do with their tails. It is made from the pistillate inflorescence of the wine palm by cutting a fragment about $50 \mathrm{~cm}$ long near its apex, removing the rachillae, beating the proximal $30 \mathrm{~cm}$ until shredding all its fibers, and leaving the distal portion as a handle. Musengues are common in small towns, where they are frequently sold on the streets, but they are not seen in larger towns or in the cities. The price of a musengue in Chimichagua, Cesar, was US\$ 0.7 in August 2009.

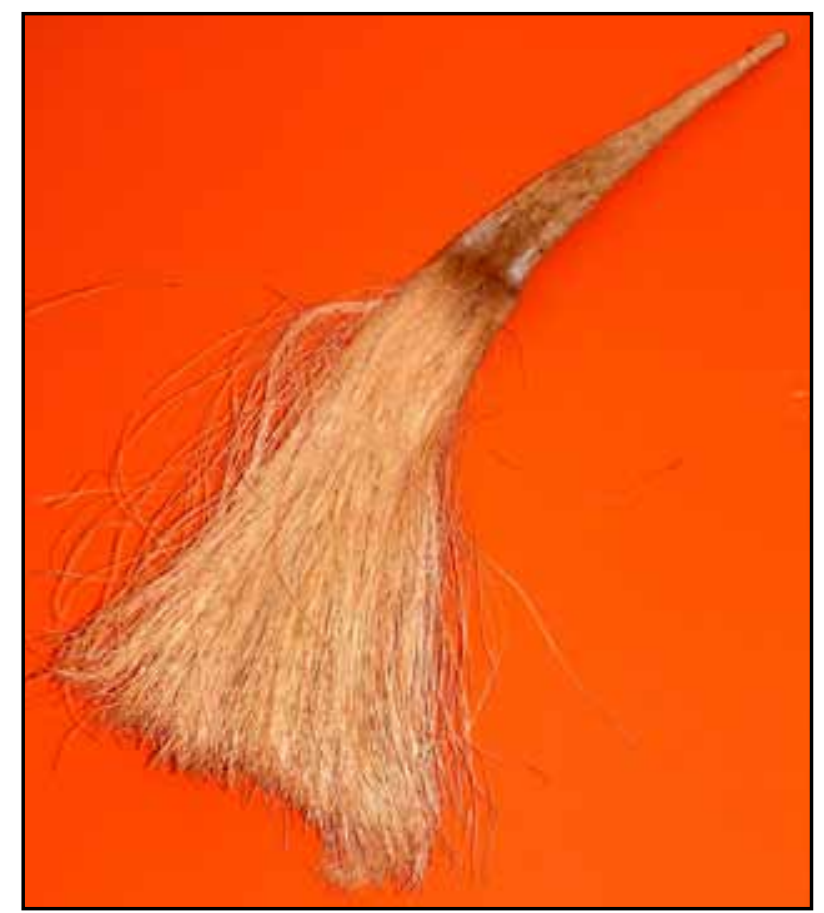

Figure 10. Fly brush (musengue) made with the female inflorescence of Attalea butyracea (Mutis ex L.f.) Wess. Boer at Chimichagua, Colombia.

The musengue is probably an artifact of African origin, judging from its restricted occurrence in an area that had a strong influence from African slaves during colonial times, from the name itself, which has a strong resemblance to words of languages from the Niger-Congo family, and from the use of similar implements in Africa, where they are made out of cow tails ( $\mathrm{H}$. Balslev, pers. comm.).

DECAYED STEMS AS A FERTILIZER. The humus resulting from the rotting stems of felled palms is harvested and applied as a fertilizer to garden plants. In Chimichagua (Cesar), it is considered the best natural fertilizer locally available. Palms are not felled for this purpose, and humus is collected from those that are cut for wine production or for other reasons. Humus is used only for household consumption and is not commercially traded.

\section{Ceremonial Uses}

LEAVES FOR PALM SUNDAY. The unexpanded leaves of $A$. butyracea are used, along with those of other palms, mainly Ceroxylon species, to greet Jesus during the procession that takes place on Easter's Palm Sunday (Figure 11). This use of the palm has been one of the most controversial, as the high demand of palm leaves among the country's mostly catholic society has strongly impacted the populations of some species. Although the invasive nature of the wine palm and its fast growth probably make it less vulnerable than the slow-growing species of Cerox- 


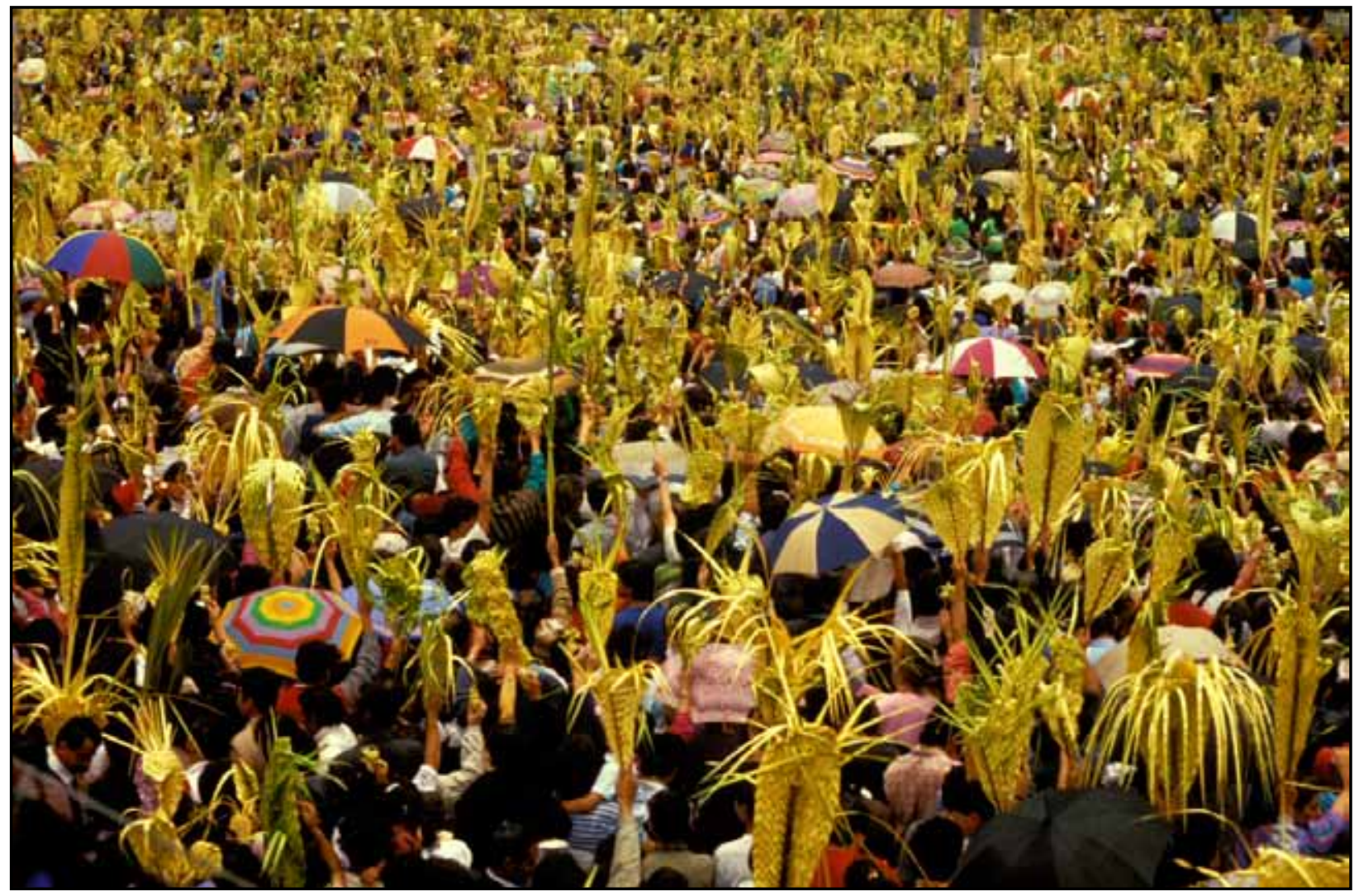

Figure 10. Leaves from Attalea butyracea (Mutis ex L.f.) Wess. Boer and Ceroxylon spp. are used during Palm Sunday in Bogotá, Colombia, 1990.

ylon, a strong control on the trade of spear leaves during Easter has been in operation during the last decade. This control seeks to abolish the use of palm spear leaves, and replace them with other symbols, like palm seedlings or expanded leaves of cultivated palms.

The major impact of the harvest of wine palm spear leaves for Easter is in the Magdalena Valley, where the palm populations are relatively small, compared to the huge human population of the nearby cities. In contrast, in the Caribbean lowlands the palm populations are much larger, and the human population is lower, resulting in a lower pressure on the palm.

Yet, the largest impact of this use is perhaps not on the wine palm itself, but on the endangered species of wax palms (Ceroxylon spp.). This is because the leaves of both palm genera are traded side by side. Telling apart the spear leaves of wine palms from those of wax palms is not easy for untrained environmental authorities, and therefore a free trade of Attalea leaves might increase the pressure on the wax palms.

\section{Discussion}

The multiple and diverse uses of Attalea butyracea make it one of the most useful plants in Colombia. In the area of Chimichagua, in the Caribbean lowlands, for example, Cruz et al. (2009) found it to be the plant with the highest number of documented uses (12 uses) a figure that increased to 17 with our own research in that region. Whereas some of its uses are occasional and of minor importance, other uses have a larger economic impact at the local and regional levels.

Some of the uses have a potential that deserves attention. Broom production, for example, might become a high volume activity if natural fibers became fashionable again as a material for brooms. A shift in fashion or a political decision to favor natural products that do not generate plastic waste could make the difference. The streets of London, for example, are swept with brooms made of natural fiber obtained from the palmyra palm (Borassus flabellifer L.) (R. Bernal, pers. obs.), whose production is the source of thriving industries in India (Davis \& Johnson 1987).

The musengue itself is an interesting topic for research. Although there are certainly no large perspectives for a trade in fly brushes, the fibers of the musengue do de- 


\section{Bernal et al. - Uses and Commercial Prospects for the Wine Palm, Attalea butyracea, in Colombia}

serve attention. They are very strong and thin, about 1.5 $\mathrm{m}$ long, and there are about 3000 filaments in a peduncle. This could be the source of a fiber comparable to cabuya (Furcraea cabuya Trel.), an important fiber crop in Colombia.

Palm heart also has commercial potential, although it has the drawback of the palm's solitary habit. However, the large amount of the palm heart produced, six to eight times as much as in $E$. oleracea or $B$. gasipaes, would make the palm worthy of attention if the growth rate turns out to be fast enough. We estimate the age of a wild palm suitable for harvesting to be about 10 years, but this estimate must be confirmed through field studies. In any case, the palm would grow faster under cultivation. Since the palms have not spread their large leaves horizontally by the time they are harvested (Figure 4), palms could be planted at 2-2.5 $\mathrm{m}$ from each other, i.e., a density of 1600 2500 palms per hectare.

Other promising products from the wine palm were studied by Devia et al. (2002). One is the seed cake obtained as a by-product of oil extraction, which has a high fiber content $(32.8 \%)$, oil $(44 \%)$, and protein $(12.7 \%)$, and is particularly interesting as a feed for bovines. The other promising product is activated charcoal from the endocarps; in Colombia, this product has a large demand and a high market price. Its production could be integrated with the use of the palm as an oil-yielding plant.

The most interesting prospect for the wine palm, however, appears to be its potential as a sugar- or ethanol-producing crop. If the destructive practice of killing the palm to obtain the sap through the meristem could be replaced by the process of extracting the sap through the inflorescences, as is done in Asia with Arenga pinnata (Wurmb) Merr. (Miller 1964, Mogea et al. 1991), B. flabellifer (Dissanayake 1986, Khieu 1996), Cocos nucifera L. (Kitze \& Johnson 1975), Caryota urens L. (Dissanayake 1977, 1986), Nypa fruticans L. (Fong 1989, Miah et al. 2003), and Phoenix sylvestris (L.) Roxb. (Kitze \& Johnson 1975), then the wine palm would be a rich source of sugar, which could be processed into ethanol.

Pulgarín \& Bernal (2004) have calculated the potential productivity of sugar from $A$. butyracea, if it were possible to tap the palm through the inflorescences. If we could keep the rate of one liter of sap per day currently obtained through the meristem (which is comparable to the sap production of the coconut palm through the inflorescence in Asia), with a sucrose content of $11.7 \%$, each palm would produce $42.7 \mathrm{~kg}$ of sugar per year. If they were planted at a distance of $9 \mathrm{~m}$ from each other, i.e., a density of 121 palms per ha, we would have a production of 5.15 tons of sugar per year. This is comparable to the national average productivity of sugarcane planted for panela (jaggery), 5.8 ton/ha/year (Ministerio de Agricultura y Desarrollo Rural 2006). Alternatively, the sap could be convert- ed into alcohol, thus turning this palm into an interesting source of biofuel.

If the palms were properly integrated with legume crops, as has been done elsewhere with the coconut (Liyanage de Silva et al. 1993), a wine palm plantation could be the base of an efficient agrosilvopastoral system. This would change the role of the palm, which sometimes is a weed in cattle pastures. The next step is to learn how to tap the palm through the inflorescence, which is probably possible, considering the different ways in which palms of various genera are tapped in Asia. If we succeed, this would be an excellent way of turning a promising resource into a real source of income and welfare.

\section{Acknowledgments}

We thank Martín Mesa, Osmelia Pedroso, Nelson Villalba, Eulisis Quintero, John Jairo Gaitán, Santiago Martínez, and many other people throughout Colombia, for sharing their knowledge on the wine palm. We also thank Lauren Raz and Manuel Macía, who kindly revised the manuscript and made valuable suggestions. Fieldwork was partially done under Project Palm Harvest Impacts in Tropical Forests-PALMS (FP7-ENB-2007-1).

\section{Literature cited}

Bernal, R., G. Galeano, Z. Cordero, P. Cruz, M. Gutiérrez, A. Rodríguez \& H. Sarmiento. 2006. Diccionario de Nombres Comunes de las Plantas de Colombia. Instituto de Ciencias Naturales, Universidad Nacional de Colombia, Bogotá. www.biovirtual.unal.edu.co/diccionario/

Cruz, M.P., A.C. Estupiñán, N.D. Jiménez, N. Sánchez, G. Galeano \& E. Linares. 2009. Etnobotánica de la región tropical del Cesar, complejo Ciénaga de Zapatosa. Pp. 417-447 in Colombia Diversidad Biótica VIII. Media y baja montaña de la Serranía de Perijá. Edited by O. Rangel. Instituto de Ciencias Naturales, Universidad Nacional de Colombia, Bogotá.

Davis, A. \& D.V. Johnson. 1987. Current utilization and further development of the palmyra palm (Borassus flabellifer L., Arecaceae) in Tamil Nadu state, India. Economic Botany 41:247-266.

Devia, J.E., A. López \& O.L. Saldarriaga. 2002. Productos promisorios del fruto de la palma de vino. Revista Universidad EAFIT (Medellín) 126:67-80.

Dissanayake, B.W. 1977. Use of Caryota urens in Sri Lanka. Pp. 84-90 in Papers of the first international Sago Symposium: The equatorial swamp as a natural resource. 5-7 July 1976, Kuching, Malaysia. Edited by Koonlin Tan. Kemajuan Kanji Sdn. Bhd., Kuala Lumpur. 
Dissanayake, B.W. 1986. Techno-economic aspects of production and utilization of two related palms kitul (Caryota urens) and palmyra. Pp: 75-85 in Sago' 85: Proceeding of the third international Sago symposium. Edited by N. Yamada \& K. Kainuma. The Sago Palm Research Fund, Tokyo.

Dugand, A. 1959. Una palma nueva Scheelea del bajo Magdalena, Colombia. Mutisia 26:1-6.

Dugand, A. 1972. Las palmeras y el hombre. Cespedesia 1:31-101.

Fong, F.W. 1989. The apung Palm traditional techniques of sugar tapping and alcohol extraction in Sarawak. Principes 33:21-6.

Henderson, A., G. Galeano \& R. Bernal. 1995. Field Guide to the Palms of the Americas. Princeton University Press, Princeton, New Jersey.

Kitze, E.D. \& D. Johnson. 1975. Commercial palm products other than oils. Principes 19:3-26.

Khieu, B. 1996. A Study on the Use of the Sugar Palm Tree (Borassus flabellifer) for Different Purposes in Cambodia. M.Sc. Thesis. Swedish University of Agricultural Sciencies, Uppsala.

Liyanage de Silva, M., H.P.S. Jayrundera, D.N.S. Fernando \& M.T.N. Fernando. 1993. Integration of legumebased pasture and cattle into coconut growing systems in Sri Lanka. Journal of Asian Farming Systems Association 1:579-588.
Marmolejo, D., M.E. Montes \& R. Bernal. 2008. Los nombres amerindios de las palmas (Palmae) de Colombia. Revista Peruana de Biología 15 (supl. 1):151-190.

Miah, M.D., R. Ahmed \& S.J. Islam. 2003. Indigenous management practices of golpata (Nypa fruticans) in local plantations in southern Bangladesh. Palms 47:185-190.

Miller, R.H. 1964. The versatile sugar palm. Principes 8:115-147.

Ministerio de Agricultura y Desarrollo Rural. 2006. El sector panelero colombiano. www.minagricultura.gov.co/archivos/Sector Panelero Colombiano.pdf

Mogea, J., B. Seibert \& W. Smits. 1991. Multipropose palms: the sugar palm (Arenga pinnata (Wurmb) Merr.). Agroforestry Systems 13:111-129.

Moreno, S., C.E. Sánchez, G. Galeano, J. Salazar \& L.J. Barrios. 1993. Cubiertas Vegetales y Maderables para la Región Húmeda de la Guajira. Programa de Arquitectura Tropical. Convenio SENA-Universidad Nacional, Bogotá.

Pérez Arbeláez, E. 1978. Plantas Útiles de Colombia. Cuarta Edición. Litografía Arco, Bogotá.

Pulgarín, N. \& R. Bernal. 2004. El potencial de la palma de vino, Attalea butyracea, como planta azucarera. Pp. 194 in Libro de Resúmenes Tercer Congreso Colombiano de Botánica. Edited by B.R. Ramírez-Padilla, D. Macías-P \& G. Varona-B. Universidad del Cauca, Popayán.

Uribe, A., P. Velásquez \& M. Montoya. 2001. Ecología de poblaciones de Attalea butyracea (Arecaceae) en un área de bosque seco tropical (Las Brisas, Sucre, Colombia). Actualidades Biológicas 23:33-39. 